\title{
Liquid-liquid extraction combined with high performance liquid chromatography-diode array-ultra-violet for simultaneous determination of antineoplastic drugs in plasma
}

\author{
Ananda Lima Sanson ${ }^{1}$, Suéllen Cristina Rennó Silva ${ }^{1}$, Matheus Coutinho Gonçalves Martins ${ }^{1}$, \\ Alexandre Giusti-Paiva ${ }^{2}$, Patrícia Penido Maia ${ }^{1 *}$, Isarita Martins ${ }^{1}$ \\ ${ }^{1}$ Faculty of Pharmacy, Laboratory of Toxicological Analysis, Federal University of Alfenas, ${ }^{2}$ Institute of Biomedical Sciences, \\ Federal University of Alfenas
}

\begin{abstract}
A liquid-liquid extraction (LLE) combined with high-performance liquid chromatography-diode array detection method for simultaneous analysis of four chemically and structurally different antineoplastic drugs (cyclophosphamide, doxorubicin, 5-fluorouracil and ifosfamide) was developed. The assay was performed by isocratic elution, with a C18 column $(5 \mu \mathrm{m}, 250 \times 4.6 \mathrm{~mm})$ and mobile phase constituted by water $\mathrm{pH} 4.0$ - acetonitrile-methanol $(68: 19: 13, \mathrm{v} / \mathrm{v} / \mathrm{v})$, which allowed satisfactory separation of the compounds of interest. LLE, with ethyl acetate, was used for sample clean-up with recoveries ranging from 60 to $98 \%$. The linear ranges were from 0.5 to $100 \mu \mathrm{g} \mathrm{mL}^{-1}$, for doxorubicin and 1 to $100 \mu \mathrm{g} \mathrm{mL}^{-1}$, for the other compounds. The relative standard deviations ranged from 5.5 to $17.7 \%$. This method is a fast and simple alternative that can be used, simultaneously, for the determination of the four drugs in plasma, with a range enabling quantification of the drugs in pharmacokinetics, bioequivalence and therapeutic drug-monitoring studies.
\end{abstract}

Uniterms: Antineoplastic drugs/simultaneous determination in plasma. Liquid-liquid extraction. Highperformance liquid chromatography/diode array detector.

Um método de extração líquido-líquido (ELL) combinado com cromatografia líquida de alta eficiênciadetector de arranjo de diodos foi desenvolvido para análise simultânea de quatro fármacos antineoplásicos quimicamente e estruturalmente diferentes (ciclofosfamida, doxorrubicina, fluoruracila e ifosfamida). O estudo foi realizado sob condições isocráticas, com coluna C18 $(5 \mu \mathrm{m}, 250$ x $4.6 \mathrm{~mm})$ e fase móvel constituída por água $\mathrm{pH}$ 4.0-acetonitrila-metanol (68:19:13, v/v/v), que permitiu separação satisfatória dos analitos de interesse. A ELL, com acetato de etila, foi utilizada para limpeza da amostra, com recuperação variando de 60 a $98 \%$. As faixas foram lineares de 0,5 a $100 \mu \mathrm{g} \mathrm{mL}^{-1}$ para doxorrubicina e $1 \mathrm{a} 100 \mu \mathrm{g} \mathrm{mL}^{-1}$ para os outros compostos. O desvio padrão relativo variou de 5,5 a 17,7\%. Este método é uma alternativa rápida e simples que pode ser usado, simultaneamente, para a determinação dos quatro fármacos em plasma, com uma faixa que permite quantificá-los em estudos de farmacocinética, bioequivalência e monitorização terapêutica.

Unitermos: Fármacos antineoplásicos/determinação simultânea em plasma. Extração líquido-líquido. Cromatografia líquida de alta eficiência/detector de arranjo de diodos.

\section{INTRODUCTION}

Antineoplastic agents are drugs used in chemotherapy which are not selective for cancer cells since they

*Correspondence: P. P. Maia, Laboratório de Análises Toxicológicas, Departamento de Análises Clínicas e Toxicológicas, Universidade Federal de Alfenas, Rua Gabriel Monteiro da Silva, 700, 37130.000 - Alfenas - MG, Brazil. E-mail: patpenido@unifal-mg.edu.br also affect the growth and reproduction of healthy cells. According to the International Agency for Research on Cancer (IARC), at least nine alkylating cytostatic drugs are classified as carcinogenic to humans (Group 1). In addition, several drugs are classified by the IARC into Groups 2A and 2B (probably and possibly carcinogenic to humans, respectively). The optimal dose should produce a maximal anti-tumor effect with acceptable levels of toxici- 
ty. In clinical practice, these drugs frequently cause toxic effects that would be considered unacceptable. Although toxicity is commonly regarded as the most important effect to control, partly because it is easier to measure, the risk of under-dosing and reduced efficacy must also be considered. In most of the current chemotherapy protocols, antineoplastics are used as a combination of agents having different mechanisms of action in order to decrease the dose of each agent individually thus keeping the synergism of therapeutic effects and minimizing the toxic effects (Turci et al., 2003)

Combination chemotherapy is administered in order to target as many types of cells in the tumor as possible. Selection of agents for combination chemotherapy regimens involves consideration of drug-specific factors such as mechanism of action, antitumor activity, and toxicity profile. Drugs that possess minimally overlapping mechanisms of action and toxicities are combined when possible (Kamil et al., 2010).

Nevertheless, as a consequence, patients may be exposed to a wide variety of substances and few methods have been described for the simultaneous determination of these drugs in plasma (Roberts et al., 2006; Turci et al., 2002; Kaestner, Sewell, 2007). In the present study, a single method was developed to determine four substances with toxicological significance in plasma.

Cyclophosphamide (CP), 2-bis(2-chloroethyl) aminotetrahydro-2H-1,3,2-oxazophosphorine-2-oxide, is one of the most commonly used antineoplastic alkylating agents. It has also been used due to its immunosuppressive properties in the treatment of autoimmune diseases as well as in renal and bone marrow transplants. $\mathrm{CP}$ has been classified as a human carcinogen (Group 1) by the IARC. Ifosfamide (IF), 3-(2-chloroethyl)-2-[(2-chloro-ethyl) amino] tetrahydro-2H-1,3,2-oxazaphosphorin-2-oxide, is a structural analogue of $\mathrm{CP}$ having alkylating activity after enzymatic activation to cytotoxic compounds. IF differs from $\mathrm{CP}$ in the transfer of one 2-chloroethyl group from the extracyclic to the endocyclic nitrogen. This results in differences in pharmacological and toxicological properties. Although IF has been shown to be carcinogenic in animals, there is no evidence of its carcinogenicity in humans and it is therefore included by the IARC in Group 3. Both cyclophosphamide and ifosfamide are widely used in the treatment of non-Hodgkin lymphomas and a variety of bone and soft tissue sarcomas. The pharmacological profile of these drugs is important and, in order to gather this information, reliable methods for the determination of oxazaphosphorines and their metabolites are necessary when determining optimal dosages (Turci et al., 2003; Ekhart et al., 2007; Baumann, Preiss, 2001).
Doxorubicin (DOX) is classified as an anthracycline, a glycosidic derivative of tetra-hydronaphthacene that belongs to the tetracycline class of antibiotics. The antineoplastic activity of these drugs has been mainly attributed to their strong interactions with DNA in target cells. These drugs can deform DNA structure and terminate its biological function. Furthermore, they can be reduced to their semiquinone form by biological reducing agents, such NADH and NADPH. Free radicals can be generated, which can attack cell components, such as membrane and DNA, and halt cell growth. According to the IARC, these agents are probably carcinogenic to humans (Group 2A). There is inadequate evidence of carcinogenicity in humans, but sufficient evidence of carcinogenicity in animals (Turci et al., 2003; Ekhart et al., 2007).

The drug 5-fluorouracil (5-FU), 5-fluoropyrimidine2,4-dione, is an antimetabolite frequently used in the treatment of malignancies including cancers of the gastrointestinal tract, lung, and breast. It acts as a competitor of pyrimidine and needs to be converted to the nucleotide level so as to exert its effect. 5-FU is classified as Group 3 (not classifiable as to carcinogenicity to humans) by the IARC based on inadequate evidence of carcinogenicity in humans and animals (Turci et al., 2003).

Several methods have been described in literature for environmental and biological monitoring of antineoplastics. The majority of the papers have described methods employing HPLC, using various detector types. Antracyclines and 5-FU can be determined by HPLC with fluorescence and UV detection, respectively. Sample extracts were injected into a $\mathrm{C} 18$ reversed-phase column with a proportion of organic solvent and buffer as mobile phase. Determination of oxazaphosphorines in serum, blood or plasma has been demonstrated by using HPLC with detection at low UV wavelengths. The sample preparation techniques commonly used involve liquid-liquid extraction (LLE) and solid phase extraction (SPE) (Boos et al., 1994; Burton, James, 1988; Hardy, Erlichman, Soldin, 1984; Margison et al., 1986; May-Manke et al., 1999; Rustum, Hoffman, 1987; Sottani et al., 2005; Martins et al., 2009).

Since HPLC assays are inexpensive and widely used, they represent a good choice for the analysis of antineoplastic drugs. Moreover, LLE is still the sample preparation technique most employed and used in routine analysis. The purpose of this investigation was to develop a single analytical LLE-HPLC-UV method for the simultaneous determination of CP, IF, 5-FU and DOX in plasma samples. 


\section{MATERIALS AND METHODS}

\section{Instrumental and operating conditions}

The HPLC equipment consisted of a Shimadzu LC10ATvp (Kyoto, Japan) gradient system equipped with a Shimadzu SIL-10AF (Kyoto, Japan) auto-injector with a $50 \mu \mathrm{L}$ loop. The column oven used was a Shimadzu CTO-10ASvp (Kyoto, Japan) operated at $25^{\circ} \mathrm{C}$. Firstly, the detection was performed with a Shimadzu SPD-M10Avp (Kyoto, Japan) diode array detector and the quantification was performed with a Shimadzu SPD-10Avp (Kyoto, Japan) UV detector at $195 \mathrm{~nm}$ and at $265 \mathrm{~nm}$. Separation was achieved by isocratic elution carried out with a mobile phase constituted of water adjusted to $\mathrm{pH} 4$ (with hydrochloric acid)- acetonitrile- methanol $(68: 19: 13, \mathrm{v} / \mathrm{v} / \mathrm{v})$, at a flow rate of $0.6 \mathrm{~mL} \mathrm{~min}^{-1}$ for $8 \mathrm{~min}$ and then $1.0 \mathrm{~mL} \mathrm{~min}^{-1}$, with a Shimpak CLC-ODS $(250 \times 4.6 \mathrm{~mm}, 5 \mu \mathrm{m})$ column protected by a similar guard-column $(40 \times 4.6 \mathrm{~mm})$. Data acquisition and treatment were performed by Class-VP software (Shimadzu).

\section{Standards and reagents}

Cyclophosphamide (CP), 5-fluorouracil (5-FU) and ifosfamide (IF) were purchased from Sigma-Aldrich Chemical Company (St. Louis, USA); doxorubicin (DOX) was purchased from Fluka (Buchs, Switzerland). Acetonitrile and methanol (HPLC grade) were obtained from Mallinckrodt ${ }^{\circledR}$ (Paris, USA). Other chemicals that were used include the following: hydrochloric acid, isopropyl alcohol, chloroform, ethyl ether and ethyl acetate from Vetec (Rio de Janeiro, Brazil). Water was distilled and purified by using a Millipore ${ }^{\circledR}$ Milli-Q Plus system (São Paulo, Brazil).

\section{Standard solutions}

Stock standard solutions were prepared by dissolution of each drug in methanol to obtain a concentration of $1 \mathrm{mg} \mathrm{mL}-1$. These solutions were stored at $-20^{\circ} \mathrm{C}$ and prepared weekly. The working solutions were prepared each day by making a 10-fold dilution of the stock solution in methanol.

\section{Sample preparation}

Aliquots of $1.0 \mathrm{~mL}$ of blank plasma spiked with the drugs (CP, IF, DOX and 5-FU) were extracted with $5.0 \mathrm{~mL}$ of ethyl acetate. The tubes were submitted to shaking for 15 minutes at $50 \mathrm{rpm}$ and then centrifuged for 10 minutes at $4000 \mathrm{x} g$. The upper organic phases were transferred to conical tubes and separated, and the aqueous layer re-extracted with $5.0 \mathrm{~mL}$ of ethyl acetate. The organic phases were combined and evaporated at $40{ }^{\circ} \mathrm{C}$ under a gentle stream of nitrogen. The residues were reconstituted in $200 \mu \mathrm{L}$ mobile phase and $50 \mu \mathrm{L}$ were injected into the HPLC system.

\section{Confidence parameters}

Validation of this study was in compliance with FDA guidelines (FDA, 2001). The following parameters were assayed: robustness, linearity, lower limit of quantification (LOQ), precision and recovery.

Robustness was performed at middle level $\left(20 \mu \mathrm{g} \mathrm{mL}^{-1}\right)$ and was explored using mobile phase flow rate and column temperature. Linearity was tested by examination of a plot of residues produced by linear regression of the responses on the amounts of the analytes in a calibration set, between 1 and $100 \mu \mathrm{g} \mathrm{mL}^{-1}$, in six replicates for each level. A calibration curve was generated in duplicate for each analytical run and consisted of a blank and six non-zero samples covering the expected range, including LOQ.

LOQ was obtained by the successive dilutions to determine the lowest concentration with accuracy and precision, as $10 \%$ RSD (relative standard deviation), with a signal-to-noise ratio of 10:1.

Precision of the method was evaluated by within-day $(n=3)$ assay using plasma spiked with the drugs at LOQ, middle and high level, during a single analytical run. The results obtained for precision were expressed as relative standard deviation (RSD \%). Recovery was determined by five replicate analyses of samples after spiking with a known mass of the analyte, in the non-contaminated samples. The results were compared with those obtained when the analyte was spiked after the clean-up procedure of the sample.

\section{Method application}

To assess the applicability of the validated method, the level of the drugs in plasma were measured after administration of the drugs at $10 \mathrm{mg} / \mathrm{kg}$ in Male Wistar rats. The animals $(n=5)$, weighing $300 \pm 20$ g, were kept under standardized conditions, according to institutional guidelines. Blood samples were collected (jugular vein cannulation) at $0 \mathrm{~min}, 15 \mathrm{~min}, 3,6,12$ and 24 hours after intravenous administration of the drugs in saline. The samples were centrifuged for $15 \mathrm{~min}$ at $2000 \mathrm{x} g$ and the plasma was stored at $-20{ }^{\circ} \mathrm{C}$ until analysis. 


\section{RESULTS AND DISCUSSION}

The HPLC method appears to be the most feasible for attaining the lower limit of detection and quantification when used for detection of multiple antineoplastics (Larson, Khazaeli, Dillon, 2003). Since patients are exposed to a wide variety of drugs, it is necessary to develop methods able to quantify multiple agents, with a single sampling. Although there is a large demand for analytical methods that simultaneously determine various compounds in biological and non biological matrices, current literature presents methods for an individual agent only, or for chemically similar groups. In this study, the aim was to develop a method able to determine the presence of four structurally different drugs (Figure 1), extensively used in clinical practice, in a single analysis. This enables more comprehensive monitoring of the therapeutic treatment to be carried out.

\section{Optimized chromatographic conditions}

The diode array detector was able to analyze, simultaneously, the extract sample at various wavelengths. In fact, this property increased the selectivity of the method since the similarity of the peaks, in the retention time of the analytes (Table I), are compared with the second derivative spectrum, in a library developed with standard solutions (Figure 1).

The HPLC behavior of CP, IF, 5-FU and DOX extracted from human plasma was isocratically examined by using a C-18 analytical column. Several mobile phases were tested and it was found that water adjusted to $\mathrm{pH} 4$ - acetonitrile-methanol $(68: 19: 13, \mathrm{v} / \mathrm{v} / \mathrm{v})$ at a flow rate of $0.6 \mathrm{~mL} \mathrm{~min}^{-1}$ for $8 \mathrm{~min}$ and $1.0 \mathrm{~mL} \mathrm{~min}^{-1}$ allowed satisfactory separation of the compounds of interest. The method robustness was demonstrated since the response of the analytes remained constant when one percent variation in the organic composition of the mobile phase, in the flow rate of mobile phase and in the column temperature was applied to the chromatographic conditions.

Before performing validation experiments, system suitability was evaluated. These tests are used to verify if the resolution and repeatability of the system are adequate for the analysis and are used for checking system performance (Shabir, 2003).

Parameters such as plate count, tailing factors and resolution were determined and compared against the specifications, as demonstrated in Table I. It is possible to observe that the system was suitable since the results of the test were considered satisfactory, according to Shabir (2003), who reported an acceptable range of plate count $>$ 2000 , resolution $>2.0$, tailing factor between 0.5 and 2.0
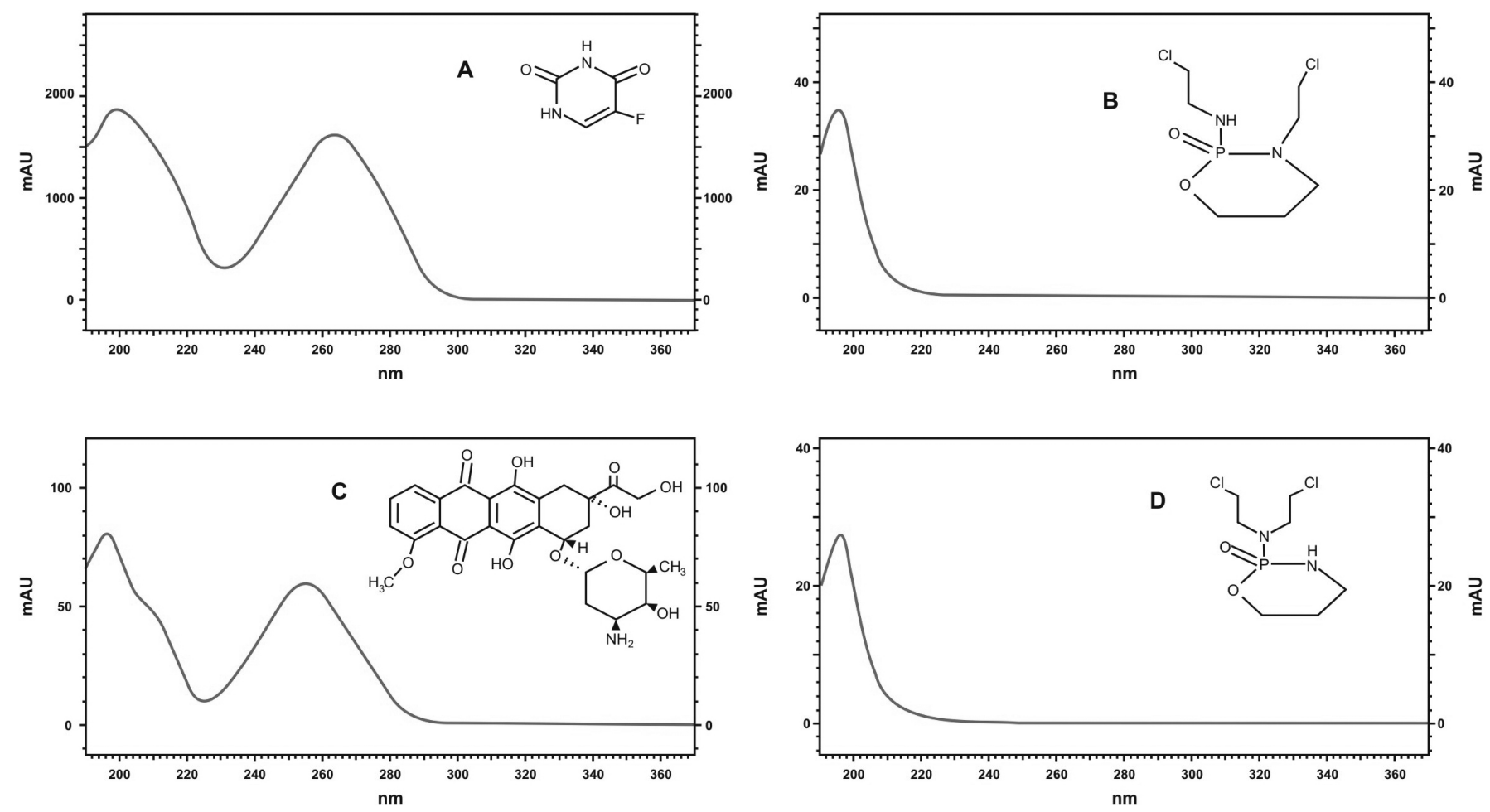

FIGURE 1 - Spectra and chemical structures of antineoplastic drugs: (A) fluorouracil, (B) ifosfamide, (C) doxorubicin and (D) cyclophosphamide. 
TABLE I - System suitability parameters* for HPLC-UV method evaluated for simultaneous determination of fluorouracil, ifosfamide, cyclophosphamide and doxorubicin

\begin{tabular}{lccccc}
\hline Analyte & Retention time $(\mathrm{min})$ & Plate count $(\mathrm{N})$ & Resolution $(\mathrm{Rs})$ & Tailing factor $(\mathrm{T})$ & Retention factor $(\mathrm{k})$ \\
\hline $5-\mathrm{FU}$ & 5.0 & 3456 & - & 1.5 & 4 \\
IF & 15.9 & 27719 & 11.9 & 1.2 & 15 \\
DOX & 16.3 & 28566 & 0.4 & 1.7 & 17 \\
CP & 18.5 & 26807 & 2.0 & 1.5 & 16 \\
\hline
\end{tabular}

*Reference values: $\mathrm{N} \geq 2000 ; \mathrm{Rs} \geq 2 ; 0.5 \leq \mathrm{T} \leq 2 ; \mathrm{k}>2$ (Shabir, 2003)

and $\mathrm{k}>2$ (Shabir, 2003). Although the values of resolution between the peaks of DOX and IF was 0.4 , these analytes were read at different wavelengths.

\section{Optimized sample treatment}

To clean-up samples, a number of experiments were then conducted to optimize the extraction efficacy. In order to find the most efficient extraction procedure for the analytes studied using LLE, different conditions were compared.

Liquid-liquid extraction is simple and a large number of solvents, pure and commercially available, can be used which provide a wide range of solubility and selectivity. Furthermore, the proteins present in the samples are denatured, eliminating the contamination of the chromatographic column (Queiroz, Collins, Jardim, 2001). Coe et al. (1996) reported an LLE procedure for the analysis of fluoruracil in plasma samples, using the $\mathrm{pH}$ adjustment to 6.0 by adding acetate buffer, followed by a saturated solution of sodium sulfate and $7.0 \mathrm{~mL}$ of ethyl acetate, with around $46 \%$ of recovery (Coe et al., 1996). For the ifosfamide and cyclophosphamide isomers, Turci et al. (2002) proposed an LLE for urine samples in which $5 \mathrm{~mL}$ of sample was adjusted to $\mathrm{pH} 7$, then extracted three times with $10 \mathrm{~mL}$ of ethyl acetate (Turci et al., 2002). A percentage of $85 \%$ for both analytes was obtained. Kümmerle et al. (2003) proposed an LLE for DOX using $500 \mu \mathrm{L}$ of biological fluid, pre-treated with a precipitation of the protein, then $250 \mu \mathrm{L}$ of acetone and $50 \mu \mathrm{L}$ of an aqueous solution of zinc sulfate $70 \%$ as a solvent extractor were added (Kümmerle et al., 2003). In our study, the principles of liquid-liquid extraction were optimized according to the following steps: type and volume of extractor solvent, shaking velocity, number of extractions totaling $10 \mathrm{~mL}$ and salting-out effect.

Various extractor solvents were tested alone and as a mixture of solvents. The response of the analytes was variable, as shown in Figure 2, and a satisfactory percentage of recovery for the four analytes was obtained with ethyl acetate. This solvent was the same used in the method of extraction by Turci et al. and Coe et al. for the analytes ifosfamide and cyclophosphamide, and 5-fluorouracil, respectively (Coe et al., 1996; Turci et al., 2002). The volume of the solvent of $10 \mathrm{~mL}$ (Figure 2) was considered optimum since a balance between the efficiency of the extraction and the environmental implications were considered in the present study.

Shaking velocity was tested at speeds of 50 and $70 \mathrm{rpm}$ in an automatic horizontal shaker. As demonstrated in Figure 2, with the rate of $70 \mathrm{rpm}$ a slightly higher percentage of recovery was observed, but this speed caused significant solvent extractor loss and increased interference in the extract. Thus, the $50 \mathrm{rpm}$ rate was considered optimum.

If a component has a low coefficient of distribution between an organic solvent and water, one or more simple extractions will not remove a lot of the components from the water. This distribution coefficient can be changed by adding salt to water. Sometimes, the difference in solubility is dramatic, since organic compounds are more soluble in pure water than in water with salt. Thus, a simple dissolution of salt in the aqueous layer can increase the distribution of an organic compound in an organic solvent; an effect commonly known as salting-out (Queiroz et al., 1995). In the present study the following salts were tested: $\mathrm{NaCl}, \mathrm{Na}_{2} \mathrm{SO}_{4}$ and $\left(\mathrm{NH}_{4}\right)_{2} \mathrm{SO}_{4}$. However, the addition of salt did not increase the percentage of recovery.

The solid phase extraction was also assessed in order to obtain a selective separation, purification and concentration of compounds present in the complex matrices. According to the literature (Baumann et al., 1999; Micoli et al., 2001; Minoia, Perbelini, 2000), the initial sorbent tested was octadecilsilane (C18) in a cartridge. However, it was not possible to optimize a condition to allow the simultaneous extraction of the four analytes, with a satisfactory percentage of recovery. Therefore, the styrene/ divinylbenzene copolymer as sorbent was tested, under different conditions for steps of conditioning, sample $\mathrm{pH}$, washing and elution. But again, these tests did not result in an optimum condition for the agents studied. This 

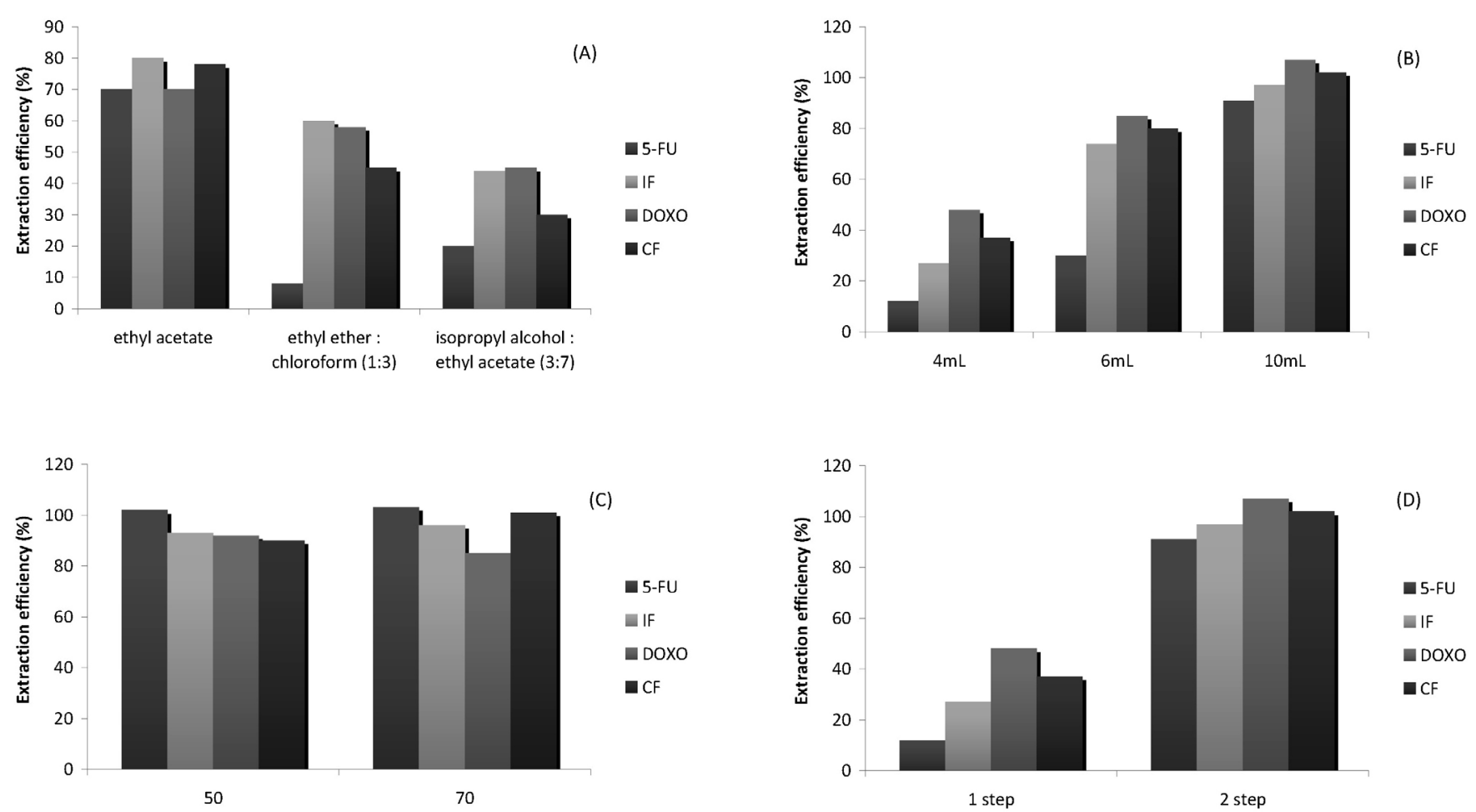

FIGURE 2 - Results expressed as extraction efficiency (\%) of fluorouracil (5-FU), ifosfamide (IF), cyclophosphamide (CP) and doxorubicin (DOX), in the LLE studies of type (A) and solvent extractor volume (B), shaking velocity $(\mathrm{C})$ and number of extractions totaling $10 \mathrm{~mL}(\mathrm{D})$.

negative result can be explained by the different physicochemical characteristics of anticancer substances, such as solubility and $\mathrm{pKa}$, factors that interfere with the SPE. Finally, silica and florisil, home-made cartridges, were tested in the matrix clean-up. These tests also produced no satisfactory results. Therefore, LLE was applied in the plasma samples and in Figure 3, it is possible to observe

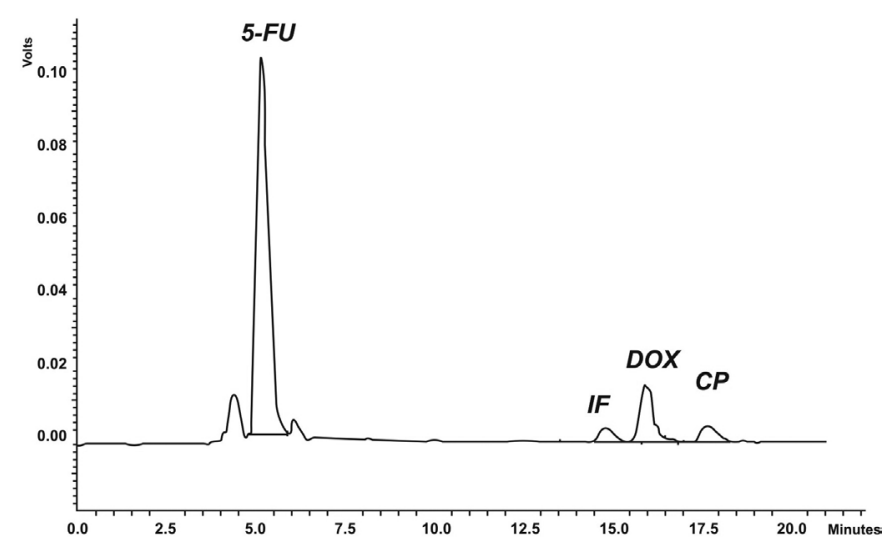

FIGURE 3 - Typical HPLC chromatograms, under optimal conditions evaluated: $20 \mu \mathrm{g} \mathrm{mL}^{-1}$ of fluoruracil (5-FU), ifosfamide (IF), doxorubicin (DOX) and cyclophosphamide (CP) extracted from plasma samples. the typical chromatograms of extracted plasma samples at a fortification level of $20 \mu \mathrm{g} \mathrm{mL}^{-1}$ for IF, CF, 5-FU and DOX by using the optimized HPLC conditions.

\section{Confidence parameters}

Calibration curves were obtained by plotting the peak area and resulted in a linear response over the range studied. The results of the linearity test are presented in Table II. The calibration curves were linear from $1-100 \mu \mathrm{g} \mathrm{mL} \mathrm{m}^{-1}$.

The method was linear in the range of $1 \mu \mathrm{g} \mathrm{mL}^{-1}$ to $100 \mu \mathrm{g} \mathrm{mL}^{-1}$ for the drugs 5-FU, IF and CF. For doxorubicin, the method was linear in the concentration range of $0.5 \mu \mathrm{g} \mathrm{mL}^{-1}$ to $100 \mu \mathrm{g} \mathrm{mL}^{-1}$. The sensitivity of the method, assessed by the value of the slope, shows that for IF, CF and DOX the method provides similar sensitivity. For 5-FU, the method demonstrated a higher sensitivity, since the value of the slope for this analyte is about 20 times larger compared to other compounds studied.

The LOQ value was $1 \mu \mathrm{g} \mathrm{mL}^{-1}$ for the analytes, except for DOX that was $0.5 \mu \mathrm{g} \mathrm{mL}^{-1}$. Thus, with these values it is possible to quantify the analytes in plasma samples (Table III) after a therapeutic dose (Goodman, Gilman, 2006). The results are in agreement with the 
TABLE II - Analytical curve parameters for simultaneous determination of fluorouracil (5-FU), ifosfamide (IF), doxorubicin (DOX) and cyclophosphamide (CP) by HPLC-DAD-UV

\begin{tabular}{lcccc}
\hline Parameters & 5-FU & IF & DOX & CP \\
\hline Range $\left(\mu \mathrm{g} \mathrm{mL}^{-1}\right)$ & $1-100$ & $1-100$ & $0.5-100$ & $1-100$ \\
Correlation coefficient $(\mathrm{r})$ & 0.992 & 0.995 & 0.998 & 0.991 \\
Slope & 633472 & 31722 & 38117 & 30413 \\
Intercept & 20300 & 67466 & 42577 & -14040 \\
\hline
\end{tabular}

TABLE III - Mean plasmatic concentration of 5-fluorouracil(5-FU), ifosfamide (IF), doxorubicin (DOX) and cyclophosphamide (CP), according to Goodman \& Gilman, 2006.

\begin{tabular}{ll}
\hline Drug & Mean plasmatic concentration \\
\hline 5 -FU & Intravenous administration: $46 \mu \mathrm{g} \mathrm{mL}^{-1}$ \\
IF & Intravenous administration: $53.0 \mu \mathrm{g} \mathrm{mL}^{-1}$ \\
& Oral administration: $52.2 \mu \mathrm{gL}^{-1}$ \\
DOX & Intravenous administration: $33.7 \mu \mathrm{g} \mathrm{mL}^{-1}$ \\
CP & Intravenous administration: $0.49 \mu \mathrm{g} \mathrm{mL}^{-1}$ \\
\hline
\end{tabular}

study conducted by Martins et al. 2009 that evaluated a range of $1-150 \mu \mathrm{g} \mathrm{mL}^{-1}$, for simultaneous determination of IF and CP.

The repeatability of the optimized method was calculated by the relative standard deviation (RSD\%) and was expressed as the following equation: $\mathrm{RSD} \%=(\mathrm{SD} /$ mean measured concentration) $\mathrm{x} 100$, and SD is the standard deviation (Table IV). The efficiency of the extraction obtained after the optimized LLE was satisfactory for the drugs studied, as summarized in Table IV.

TABLE IV - Precision and recovery of the method for simultaneous analysis of fluorouracil (5-FU), ifosfamide (IF), doxorubicin (DOX) and cyclophosphamide (CP) by LLEHPLC-UV in plasma

\begin{tabular}{lccc}
\hline & \multicolumn{3}{c}{ Level $\left(\boldsymbol{\mu g} \mathbf{~ m L}^{-1}\right)$} \\
\cline { 2 - 4 } & $\mathbf{1}$ & $\mathbf{2 0}$ & $\mathbf{1 0 0}$ \\
\hline 5-FU & 13.4 & 11.3 & 5.7 \\
$\quad$ RSD \% & 74 & 85 & 91 \\
$\quad$ recovery (\%) & & & \\
IF $\quad 17.7$ & 5.5 & 9.8 \\
$\quad$ intra-assay (RSD\%) & 91 & 93 & 96 \\
$\quad$ recovery (\%) & & & \\
DOX & 17.6 & 14.1 & 8.6 \\
$\quad$ intra-assay (RSD\%) & 81 & 88 & 97 \\
$\quad$ recovery (\%) & & & \\
CP $\quad$ intra-assay (RSD\%) & 8.6 & 12.5 & 7.5 \\
$\quad$ recovery (\%) & 60 & 90 & 98 \\
\hline
\end{tabular}

Recoveries near $100 \%$ were in compliance with the FDA guide (FDA, 2001). The results obtained with the optimized LLE can be considered satisfactory since the method was precise and accurate. The results were compared with those in the literature, such as the study of Coe et al. (1996) that obtained, for 5-FU, an average recovery of $46 \%$ and Turci et al. (2002), that reported a recovery of $85 \%$ for IF and CF in urine, but using a total volume of $30 \mathrm{~mL}$ of solvent extractor (Coe et al., 1996; Turci et al., 2002).

\section{Method application}

In order to demonstrate the applicability of the validated method the drugs were administered to rats. First, a calibration curve for each drug was obtained by adding 5-FU, IF and CP to aliquots of a pool of plasma of rats at concentrations of 1,20 and $100 \mu \mathrm{g} \mathrm{mL}^{-1}$, and DOX at concentrations of $0.5,20$ and $100 \mu \mathrm{g} \mathrm{mL}^{-1}$. These samples were submitted to the method, then the signals obtained were plotted to obtain the analytical curves and linearity values. To check the influence of the matrix, a correlation test was performed comparing the standard curves obtained for each analyte in human plasma to curves obtained in plasma from rats. A correlation between the curves $(r>0.85)$ was observed, confirming that the method validated in human plasma can be used for plasma of animals.

The samples were obtained through the administration of a single intravenous infusion $(2 \mathrm{~mL})$ of saline containing antineoplastic agents studied in therapeutic concentration. We also obtained a sample blank by injecting only $2 \mathrm{~mL}$ of saline without drugs. The blood samples were then collected at the timepoints of 15 minutes, 3, 6, 12 and 24 hours after the infusion. After separation of plasma, it was submitted to the optimized LLE and the data were used to obtain the kinetic curve of each drug. In Figure 4 it can be observed that the maximum concentration of antineoplastics studied was obtained from the first collection time (15 minutes), as expected for an intravenous infusion. For DOX, a kinetic curve was not constructed since the plasma concentration was only quantified at the first timepoint collection. 


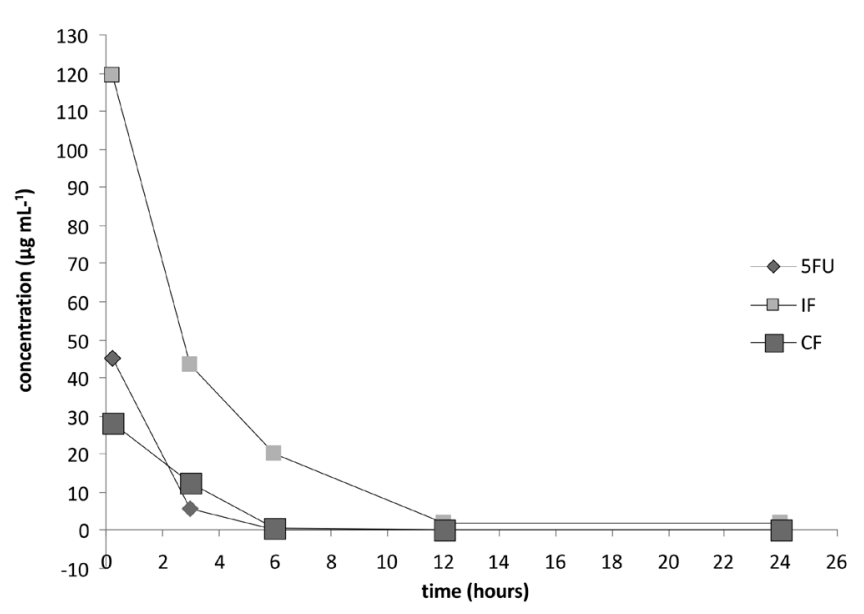

FIGURE 4 - Kinetic curve of antineoplastic drugs 5-fluorouracil (-5-FU), ifosfamide (IF) and cyclophosphamide (CP), obtained after a single intravenous infusion in rats.

\section{CONCLUSIONS}

In the present study, an LLE-HPLC-DAD method for the simultaneous analysis of four chemically and structurally different antineoplastic drugs was developed. This method is simple, fast and presented values of linearity, robustness, precision and efficiency of extraction in the range evaluated. Thus, the features of the proposed method to determine the antineoplastic agents fluorouracil, ifosfamide and cyclophosphamide in plasma, i.e., good analytical performance, simplicity and low cost of the technique, make this approach very convenient for application in therapeutic drug monitoring and pharmacokinetic studies. And, for doxorubicin, it can be applied in the diagnosis of poisoning, since it can detect/quantify concentrations above the therapeutic range.

\section{ACKNOWLEDGEMENTS}

This research was supported by the National Council for Scientific and Technological Development (CNPq)/ Brazil (grant from MCT-CNPq 54/2005, nº 402630/2005), and by the Fundação de Amparo à Pesquisa do Estado de Minas Gerais (FAPEMIG)/Brazil (process number CDSAPQ-4487-4.04/07).

\section{REFERENCES}

BAUMANN, F.; PREISS, R. Cyclophosphamide and related anticancer drugs. J. Chromatogr. B, v.764, p.173-192, 2001.
BAUMANN, F.; LORENZ, C.; JAEHDE, U.; PREISS, R. Determination of cyclophosphamide and its metabolites in human plasma by high-performance liquid chromatographymass spectrometry. J. Chromatogr. B, v.729, p.297-305, 1999.

BOOS, J.; KÜPKER, F.; BLASCHKE, G.; JÜRGENS, H. Trofosfamide metabolism in different species-ifosfamide is the predominant metabolite. Cancer Chemother. Pharmacol., v.33, p.71-76, 1994.

BURTON, L.C.; JAMES, C.A. Rapid method for the determination of ifosfamide and cyclophosphamide in plasma by high-performance liquid chromatography with solid-phase extraction. J. Chromatogr., v.431, p.450-454, 1988.

COE, R.A.; EARL, R.A.; JOHNSON, T.C.; LEE, J.W. Determination of 5-fluorouracil in human plasma by a simple and sensitive reversed-phase HPLC method. $J$. Pharm. Biomed. Anal., v.14, p.1733-1741, 1996.

EKHART, C.; GEBRETENSAE, A.; ROSING, H.; RODENHUIS, S.; BEIJNEN, J.H.; HUITEMA, A.D.R. Simultaneous quantification of cyclophosphamide and its active metabolite 4-hydroxycyclophosphamide in human plasma by high-performance liquid chromatography coupled with electrospray ionization tandem mass spectrometry (LC-MS/MS). J. Chromatogr. B, v.854, p.345-349, 2007.

FOOD AND DRUG ADMINISTRATION. FDA. Bioanalytical methods validation for human studies: guidance for industry. Rockville: FDA, 2001. 13 p.

GOODMAN \& GILMAN's the pharmacological basis of therapeutics. 11 ed. New York: McGraw- Hill, 2006. 2021 p.

HARDY, R.W.; ERLICHMAN, C.; SOLDIN, S.J. Highperformance liquid chromatographic measurement of cyclophosphamide in serum. Ther. Drug Monit., v.6, p.313318, 1984.

KAESTNER, S.; SEWELL, G. Dose-banding of carboplatin: rationale and proposed banding scheme. J. Oncol. Pharm. Pract., v.13, p.109-117, 2007.

KAMIL, N.; KAMIL, S; AHMED, S. P.; ASHRAF, R.; KHURRAM, M.; ALI, M.O. Toxic effects of multiple anticancer drugs on skin. Pak. J. Pharm. Sci, v.23, p.7-14, 2010. 
KÜMMERLE, A.; KRUEGER, T.; DUSMET, M.; VALLET, C.; PAN, Y.; RIS, H.B.; DECOSTERD, L.A. A validated assay for measuring doxorubicin in biological fluids and tissues in an isolated lung perfusion model: matrix effect and heparin interference strongly influence doxorubicin measurements. J. Pharm. Biomed. Anal., v.33, p.475-494, 2003.

LARSON, R.R.; KHAZAELI, M.B.; DILLON, H.K. Development of an HPLC Method for simultaneous analysis of five antineoplastic agents. Appl. Occup. Envir. Hyg., v.18, p.109-116, 2003.

MARGISON, J.M.; WILKINSON, P.M.; CERNY, T.; THATCHER, N. A simple quantitative HPLC assay for ifosfamide in biological fluids. Biomed. Chromatogr., v.1, p.101-103, 1986.

MARTINS, I.; SOUZA, J.O.; SANSON, A.L.; VIEIRA, E.P.; GIUSTI-PAIVA, A. Simultaneous Determination of cyclophosphamide and ifosfamide in plasma using SPEHPLC-UV method. Lat. Am. J. Pharm., v.28, p.41-46, 2009.

MAY-MANKE, A.; KROEMER, H.; HEMPEL, G.; BOHNENSTENGEL, F.; HOHENLÖCHTER, B.; BLASCHKE, G.; BOOS, J. Investigation of the major human hepatic cytochrome P450 involved in 4-hydroxylation and $\mathrm{N}$-dechloroethylation of trofosfamide. Cancer Chemother. Pharmacol., v.44, p.327-334, 1999.

MICOLI, G.; TURCI, R.; ARPELLINI, M.; MINOIA, C.; Determination of 5-fluorouracil in environmental samples by solid-phase extraction and high-performance liquid chromatography with ultraviolet detection. J. Chromatogr. $B$, v.750, p.25-32, 2001.

MINOIA, C.; PERBELLINI, L. Monitoraggio ambientale e biologico dell'esposizione professionale a xenobiotici: chemoterapici antiblastici. Milan: Morgan, 2000. v.3.

QUEIROZ, S.C.N.; COLLINS, C.H.; JARDIM, I.C.S.F. Métodos de extração e/ou concentração de compostos encontrados em fluidos biológicos para posterior determinação cromatográfica. Quim. Nova, v.24, p.68-76, 2001 .
QUEIROZ, R.H.C.; LANCHOTE, V.L.; BONATO, P.S.; CARVALHO, D. Simultaneous HPLC analysis of tricyclic antidepressants and metabolites in plasma samples. Pharm. Acta Helv. Zurich, v.70, p.181-186, 1995.

ROBERTS, S.; KHAMMO, N; MCDONNELL, G.; SEWELL, G.J. Studies on the decontamination of surfaces exposed to cytotoxic drugs in chemotherapy workstations. J. Oncol. Pharm. Pract,. v.12, p.95-104, 2006.

RUSTUM, A.M.; HOFFMAN, N.E. Determination of cyclophosphamide in whole blood and plasma by reversedphase high-performance liquid chromatography. $J$. Chromatogr. B, v.422, p.125-134, 1987.

SHABIR, G.A. Validation of high-performance liquid chromatography methods for pharmaceutical analysis: Understanding the differences and similarities between validation requirements of the US Food and Drug Administration, the US Pharmacopeia and the International Conference on Harmonization. J. Chromatogr. A, v.987, p.57-66, 2003.

SOTTANI, C.; TRANFO, G.; FARANDA, P.; MINOIA, C. Highly sensitive high-performance liquid chromatography/ selective reaction monitoring mass spectrometry method for the determination of cyclophosphamide and ifosfamide in urine of health care workers exposed to antineoplastic agents. Rapid Commun. Mass Spectrom., v.19, p.27942800, 2005.

TURCI, R.; SOTTANI, C.; RONCHI, A.; MINOIA, C. Biological monitoring of hospital personnel occupationally exposed to antineoplastic agents. Toxicol. Lett., v.134, p.57-64, 2002.

TURCI, R.; SOTTANI, C.; SPAGNOLI, G.; MINOIA, C. Biological and environmental monitoring of hospital personnel exposed to antineoplastic agent: a review of analytical methods. J. Chromatogr. B, v.789, p.169-209, 2003.

Received for publication on $13^{\text {rd }}$ July 2010 Accepted for publication on $10^{\text {th }}$ December 2010 